Siposné Kecskeméthy Klára ezredes:

\title{
A NATO 2030 JELENTÉS - STRATÉGIAI PRIORITÁSOK ÚJ MEGKÖZELÍTÉSBEN
}

DOI: $10.35926 /$ HSZ.2021.4.1

ÖSSZEFOGLALÓ: A NATO 2030 jelentés szerint a Szövetségnek az elkövetkező évtizedben a mainál egy sokkal összetettebb stratégiai környezethez kell alkalmazkodnia. Ezt az időszakot a rendszerszintü rivalizálás visszatérése, Oroszország és Kína felemelkedése, valamint a feltörekvő és diszruptív technológiák (EDT') növekvő szerepe jellemzi, ugyanakkor fokozott transznacionális fenyegetésekkel és kockázatokkal is szembe kell néznie. A NATO 2030 jelentés jó lehetőséget nyújt a Szövetség folyamatos megújulási képességének és a változó világhoz való alkalmazkodásának áttekintésére. A tanulmányban a szerző a NATO 2030 jelentés stratégiai prioritásait, illetve a Szövetség partnerkapcsolataira vonatkozó ajánlásait is értékeli. A NATO partnerségi kezdeményezések (Partnerség a Békéért, Mediterrán Párbeszéd, Isztambuli Együttmüködési Kezdeményezés, Partnerek a Világban) kulcsfontosságú eszközei a kooperatív biztonság megteremtésének és a partnerekkel való együttmüködésnek.

KULCSSZAVAK: Hármak Bizottsága, Harmel-jelentés, NATO 2030 jelentés, Berlini Partnerségi Csomag, Mediterrán Párbeszéd, Isztambuli Együttmüködési Kezdeményezés

\section{BEVEZETÉS}

Az Észak-atlanti Szerződés Szervezete 2020. április 4-én ünnepelte alapításának 70. évfordulóját. Az előkészítése és létrehozása során a legoptimistább emberek sem gondolták, hogy a Szövetség ilyen szép kort megél. A NATO a kezdetektől fogva nem csupán katonai, hanem politikai szövetség is volt, amely szerepet vállalt tagjai egyesítésében a közös stratégiai elképzelés, a közös értékek, érdekek és sorsközösség mentén. Ma a történelem legsikeresebb szövetsége, amelynek határai Észak-Amerika csendes-óceáni partvidékétől a Feketetengerig húzódnak. A tagországokban közel egymilliárd ember él, és a világ GDP-jének felét tagországai adják. A NATO 2030 jelentés jó alkalom arra, hogy számvetést készítsünk és áttekintsük a Szövetség folyamatos megújulási képességét és adaptációját a változó világhoz. Tesszük ezt annak ismeretében, hogy a Szövetségen belüli viták nem új keletűek, mert a Szervezetnek fennállása óta mind a hidegháború idején, mind a posztbipoláris korszakban számos alkalommal kellett megújulnia és a feszültségeket oldania.

1 Emerging and disruptive technologies. 


\section{A NATO ADAPTÁCIÓJA A HIDEGHÁBORÚ IDEJÉN}

A NATO története során a hidegháború időszakában belső viták többször bontakoztak ki a tagállamok között, amelyekre megoldást kellett találni, miközben a Szövetségnek is meg kellett újulnia. A Hármak Bizottsága - amelyet az első „,három bölcsként” is emlegetnek 1951-ben jött létre. Feladata javaslatok megfogalmazása volt a tagországok hadipari termelésének bővítésére úgy, hogy az az egyes országok gazdasági újjáépítését ne hátráltassa. ${ }^{2}$ Az 1956-os szuezi válság és a magyar forradalom jellemezte nemzetközi helyzetben a NATO története során másodszor kért fel szakértőket és állította fel az ún. második „Három bölcs" Bizottságot. ${ }^{3}$ A Bizottság jelentése a NATO nem katonai tevékenységének javítására irányult. Általános irányelveket javasoltak a tagországok és az Észak-atlanti Tanács (NAC $\left.{ }^{4}\right)$ közötti eredményesebb kommunikáció, a könnyebb döntéshozatal érdekében és az eljárások hatékonyabbá tételével kapcsolatban. Ekkortól vált napi gyakorlattá a politikai konzultáció. ${ }^{5}$

A tagállamok közötti vitás kérdések rendezésére új jószolgálati és közvetítő mechanizmus bevezetését tanácsolták. Ajánlásaik alapján létrejött a Tudomány a Békéért és Biztonságért Program $\left(\mathrm{SPS}^{6}\right)$, amelynek célja a tagállamok együttmüködő projektjeinek elősegítése, a nemzetközi tapasztalatcserék stimulálása és a kutatásokra fordított nemzeti erőforrások megtérülésének maximalizálása volt. Célzott nemzeti tájékoztatási programok indultak, nemzetközi tájékoztató tiszteket neveztek ki. Azt javasolták, hogy a tagállamok a nemzeti politikájuk kialakítása során legyenek figyelemmel a többi NATO-tagállam érdekeire is. Az elért konszenzust a nemzeti politikák során is érvényesíteni kellett, s amennyiben ezt nem tette meg egy tagállam, akkor annak okáról tájékoztatnia kellett a NAC-et. E gondolatok és javaslatok egy része napjainkban is visszaköszön.

A Szövetségen belül a hatvanas évek második felére ismét belső feszültségek halmozódtak fel: Franciaország kilépése a NATO katonai szervezetéből, az Amerikai Egyesült Államok vietnami intervenciója, valamint a katonai kiadások és a közös terhek megosztása az állandóan visszatérő legfontosabb vitás kérdések voltak. Ezek kivizsgálására Pierre Harmel belga külügyminiszter vezetésével négy bizottságot hoztak létre.

A Szövetség jövőbeni feladatai címü Harmel-jelentés ${ }^{8}$ alapvetése a Szövetség kettős, politikai és katonai feladatrendszerének elválaszthatatlansága, a legfontosabb célkitüzése egy stabilabb nemzetközi rendszer megteremtése volt, amelyet a konzultációs rendszer további kiszélesítésén alapuló közös megközelítéssel javasoltak elérni. A Szövetség ezután az új politikai, katonai és technológiai körülményekhez illeszkedő új stratégiát fogadott el. Az ún. rugalmas reagálás doktrína a kihívások természetétől függően a lehetséges válaszok kiegyensúlyozottabb és rugalmas megfogalmazását tette lehetővé mind a nukleáris, mind a hagyományos fegyverek vonatkozásában. A Harmel-jelentés a Szövetség egyik

2 A Bizottság tagjai W. Averell Harriman, az Európai Újjáépítési Program (European Recovery Program, a Marshallterv) amerikai koordinátora, Sir Edwin Plowden brit gyáriparos és Jean Monnet francia közgazdász voltak.

3 Tagjai az olasz Gaetano Martino, a norvég Halvard Lange és a kanadai Lester Pearson külügyminiszterek voltak.

4 North Atlantic Council.

5 Gazdag Ferenc: Az első negyven év. A NATO 1949-1989 között. In: Dunay Pál - Gazdag Ferenc: Az Észak-atlanti Szerződés szervezete - Tanulmányok és dokumentumok. Stratégiai és Védelmi Kutatóintézet, Budapest, 1997, 35.

6 Science for Peace and Security Programme. NATO E-Library, 18. 08. 2020. https://www.nato.int/cps/en/natohq/ topics_85373.htm (Letöltés időpontja: 2021.02.25.)

7 Az első a Kelet és a Nyugat közötti kapcsolatokkal, a második a Szövetségen belüli kapcsolatokkal, a harmadik az általános védelempolitikával, a negyedik pedig a más országokkal fenntartott kapcsolatokkal foglalkozott.

8 The Harmel Report: full reports by the rapporteurs on the future tasks of the Alliance. http://www.bits.de/NRANEU/ nato-strategy/Harmel_Report_complete.pdf (Letöltés időpontja: 2021. 03. 19.) 
legkoncepciózusabb dokumentuma volt, amely akkor jelentősen hozzájárult az európai helyzet javulásához. ${ }^{9}$

\title{
A NATO-N BELÜLI VITÁK A POSZTBIPOLÁRIS KORSZAKBAN
}

\author{
„A NATO-n belüli politikai különbségek azért veszélyesek, mert lehetőséget adnak a \\ külső szereplőknek, különösen Oroszországnak és Kínának, hogy kihasználjanak egyes \\ tagállamokat, és ezzel veszélyeztessék a NATO kollektív érdekeit és biztonságát."10
}

A posztbipoláris korszak után megfogalmazódott, hogy mivel a NATO életre hívója, a Szovjetunió és a volt szocialista országokat tömörítő Varsói Szerződés is megszünt, ezért a Szervezetnek sincs további létjogosultsága. A már 72 éve fennálló katonai szövetség napjainkban ismét új értelmet keres saját létezésére. Az alapítása utáni évtizedekben is sok kritika érte, de az elmúlt időszakban a Szövetség müködésével, az egyes müveleteivel (jugoszláviai légicsapások, Irak, Afganisztán, líbiai légicsapások stb.) és a tagországok védelmi kiadásaival kapcsolatban belső bírálatokat is megfogalmaztak. ${ }^{11}$

Már 2011-ben is az volt a Szövetség egyik legnagyobb kihívása, hogy a rendelkezésre álló szükös eröforrásokat milyen prioritások mentén lehet a lehető leghatékonyabban felhasználni. A széles körü biztonsági kihívások kezeléséhez katonai képességek kellenek, a katonai képességek kialakításához, fejlesztéséhez pedig a megfelelő és elégséges erőforrások allokálása szükséges. Robert Gates amerikai védelmi miniszter a 2011. június 10-i beszédében értékelte a transzatlanti teherviselést és a költségek megoszlását a két kontinens között. Elemezte az afganisztáni ISAF müveletet, a líbiai misszió kapcsán kitért a Szövetség képességeire és az egyes tagállamok müveletekben való részvételi hajlandóságára. Kritikusan fogalmazott a „,partvonal mentén ülő tagállamokról” (allies sitting on the sidelines), amelyek nem voltak olyan katonai képesség birtokában, hogy a légicsapásokban részt vehessenek. Gates kétszintü politikai-katonai szövetségként jellemezte a NATO-t, amelyben az egyes tagországok az ún. ,, soft security” tevékenységre szakosodtak (békefenntartás, humanitárius műveletek), mások pedig a tényleges hadműveleteket hajtották végre. Megemlítette, hogy az összeurópai védelmi kiadás a 2001. szeptember 11-ét követő évtizedben mintegy 15\%-kal csökkent. ${ }^{12}$ Felrótta, hogy az akkor 28 tagú szövetségböl mindössze öt ország (Amerikai Egyesült Államok, Nagy-Britannia, Franciaország, Görögország és Albánia) védelmi költségvetése haladta meg a GDP $2 \%$-át. ${ }^{13}$

${ }^{9}$ Gazdag: i. m. 39-40.

${ }^{10}$ NATO 2030: United for a new era - Analysis and recommendations of the Reflection Group appointed by the NATO Secretary General. Brussels, 25. 10. 2020., 9. https://www.nato.int/nato_static_fl2014/assets/pdf/2020/12/ pdf/201201-Reflection-Group-Final-Report-Uni.pdf (Letöltés időpontja: 2021. 02. 16.)

11 Szenes Zoltán - Siposné Kecskeméthy Klára: NATO 4.0 and Hungary; 20 years of membership, 30 years of cooperation. Zrínyi Kiadó, Budapest, 2019.

12 Reflections on the status and future of the transatlantic alliance > Security \& Defence Agenda. 10. 06. 2011. https:// www.europarl.europa.eu/meetdocs/2009_2014/documents/sede/dv/sede190911robertgates_/sede190911robertgates_ en.pdf (Letöltés időpontja: 2021. 02. 15.)

13 A NATO honlapján a védelmi kiadásokra vonatkozóan a Szervezet alapításától kezdve napjainkig rendelkezésre állnak az adatok, így pontosan nyomon követhető az egyes tagországok védelmi kiadásainak alakulása. Information on defence expenditures. NATO E-Library, 16. 03. 2021. https://www.nato.int/cps/en/natohq/topics_49198. htm? selectedLocale=en (Letöltés időpontja: 2021. 03. 19.); Defence Expenditure of NATO countries (2013-2020). NATO Press Release, Communique PR/CP(2020)104, 21. 10. 2020. https:/www.nato.int/nato_static_fl2014/ assets/pdf/2020/10/pdf/pr-2020-104-en.pdf (Letöltés időpontja: 2021. 02. 16.) 
Pár évvel később Robert Gates gondolatai visszaköszöntek. Donald Trump amerikai elnök többször bírálta a Szövetséget és a szövetségeseket nagyobb anyagi áldozatvállalást követelve, és „,idejétmúltnak” nevezte a NATO-t. ${ }^{14}$ A 2016-os elnökválasztási kampányban a The New York Timesnak adott interjúban kritikával illette az érintett tagországokat, mert nem teljesítették a védelmi kiadásokra vonatkozó kötelezettségeiket. Megfogalmazta, hogy az Amerikai Egyesült Államok esetleg nem teljesíti az 5. cikk szerinti kölcsönös védelmi kötelezettségvállalását, mert a NATO-tagállamok túlnyomó többsége nem fordítja a GDP 2\%-át védelemre. Az elmúlt években az Amerikai Egyesült Államok annyit költött védelemre, mint az összes többi tagország együttvéve. A 2017. május 25-i brüsszeli NATOcsúcsértekezleten elhangzott beszédében egyértelmüvé tette, hogy a Szövetségnek nagyobb hangsúlyt kell fektetnie a terrorizmusra, a migrációra, az orosz fenyegetésre, valamint a keleti és a déli szárnyára. ${ }^{15}$

Emmanuel Macron francia elnök 2019. november 5-én a The Economistnak adott nyilatkozata megdöbbentette a szövetségeseket. Elmondása szerint nem tudja, hogy a kölcsönös segítségnyújtást garantáló 5. cikkben megfogalmazott kollektív védelem továbbra is érvényes-e. Utalt arra, hogy az európai tagállamok nem várhatják el az Amerikai Egyesült Államoktól, hogy megvédje öket. A NATO ,agyhaláláról” (brain-dead) beszélt Washington stratégiai koordinációjának és vezetésének hiánya miatt. Macron szerint Európának stratégiai szinten, geopolitikai hatalomként kell gondolkodnia, különben nem tudja majd a sorsát irányítani. ${ }^{16}$ Az Amerikai Egyesült Államok és NATO-szövetségesei közötti stratégiai döntéshozatal koordinációjának hiányát példázták az egyoldalú amerikai és török döntések Szíriában. Macron emlékeztetett Trump elnök döntésére az amerikai csapatok Északkelet-Szíriából történő kivonásáról, amely meglepetésként érte a szövetségeseket. Ez egyben teret adott Törökországnak arra, hogy a határai mentén ún. biztonsági zónát hozzon létre, kiüzve a területről azokat a kurd erőket, amelyek az Iszlám Állam elleni harcban segítették az Amerikai Egyesült Államokat. Macron már akkor bírálta a NATO-t, mert nem reagált a török offenzívára.

\section{NATO 2030 JELENTÉS}

A Macron-nyilatkozat azonnali cselekvésre késztette a Szövetséget. 2019 decemberében a NATO-tagállamok állam- és kormányfőinek londoni találkozóján a résztvevők felkérték Jens Stoltenberg NATO-fötitkárt, hogy indítson el egy átfogó önvizsgálati folyamatot (ForwardLooking Reflection Process). ${ }^{17}$ Stoltenberg 2020. március 31-én felkérte a Reflection Group

\footnotetext{
14 Transcript: Donald Trump on NATO, Turkey's Coup Attempt and the World. The New York Times, 21. 07.2016. https://www.nytimes.com/2016/07/22/us/politics/donald-trump-foreign-policy-interview.html; Káncz Csaba: Így kerüli meg hazánkat a NATO és az EU - betelt a pohár. Privátbankár, 2020. 12. 04. https://privatbankar.hu/ cikkek/makro/igy-keruli-meg-hazankat-a-nato-es-az-eu--betelt-a-pohar.html (Letöltések időpontja: 2021. 02. 16.)

15 Remarks by Donald Trump, President of the United States at the dedication of the 9/11-Article 5 Memorial. https:/www.nato.int/nato_static_fl2014/assets/audio/audio_2017_05/20170525_170525f.mp3 (Letöltés időpontja: 2021. 02. 16.)

${ }^{16}$ Emmanuel Macron warns Europe: NATO is becoming brain-dead. The Economist, 07. 11. 2019. https://www. economist.com/europe/2019/11/07/emmanuel-macron-warns-europe-nato-is-becoming-brain-dead (Letöltés időpontja: 2021. 02. 16.)

17 NATO 2030: United for a new era... 3.
} 
szakértőit. ${ }^{18}$ A tíz vezető személyiségből álló csoport arra kapott felhatalmazást, hogy vizsgálja meg a NATO jelenlegi helyzetét és jövőbeni szerepét, vagyis tegyen javaslatokat a Szövetség egységének, szolidaritásának, kohéziójának és a transzatlanti köteléknek a megerősítésére, a szövetségesek közötti politikai konzultáció és koordináció fokozására, valamint a NATO politikai szerepének és releváns eszközeinek megerősítésére a biztonságát érintő, bármely stratégiai irányból jövő fenyegetések és kihívások kezelésére vonatkozóan. ${ }^{19}$

A tízfős szakértői csoport 2020. november 25-én adta át a jelentését a NATO-főtitkárnak. A NATO-tagállamok külügyminiszterei 2020. december elején kétnapos virtuális tanácskozást tartottak, ahol bemutatták a NATO 2030: Egységben egy új korszakért címü 67 oldalas jelentést. ${ }^{20}$ A vitairat szerzői gárdáját Thomas de Maizière volt német védelmi miniszter és Wess Mitchell, az amerikai Külügyminisztérium volt Európa-ügyi megbízottja vezette. A Reflection Group tagja volt a brit John Bew, a kanadai Greta Bossenmaier, a dán Anja Dalgaard-Nielsen, a francia Hubert Védrine, az olasz Marta Dassù, a holland Herna Verhagen, a lengyel Anna Fotyga és a török Tacan Ildem.

A szakértői csoport összetétele véleményünk szerint nem tükrözi a posztbipoláris korszak bővítési körei eredményeként a Szövetség megváltozott földrajzi fókuszát, pedig a 30 tagországból 14 egykori szocialista ország, jelentős részük a Varsói Szerződés tagállama volt. A jelentés megfogalmazói között csak a lengyel szakértő képviselte a kelet-középeurópai régiót. $^{21}$

A jelentés három részből áll: 1. a jövőkép és a legfontosabb megállapítások; 2. a biztonsági és a politikai környezet értékelése; 3. az ajánlások. A NATO 2030 jelentésben a Szövetség jövőképére vonatkozó legfontosabb megállapítások és javaslatok között az alábbi stratégiai prioritások szerepelnek: a védelmi szövetség müködésének adaptálása, alkalmazkodás az új és meröben más biztonsági környezethez és helyzethez, a válsághelyzetekben gyorsabb döntéshozatal és összetartóbb, egységesebb fellépés. A NATO-nak egy sokkal összetettebb stratégiai környezethez kell alkalmazkodnia, amelyet a geopolitikai rivalizálás, konfrontáció Oroszországgal, Kína felemelkedése és az EDT-k növekvő szerepe jellemez, ugyanakkor számos országhatárokon túlnyúló fenyegetéssel és kockázattal kell szembenéznie.

A szakértők összességében 138 ajánlást fogalmaztak meg a szövetséges és partnerállamok döntés-előkészítői és döntéshozói számára, amelyek közül az alábbiak a legfontosabbak. ${ }^{22}$

Szükségesnek ítélik a NATO alapfeladatainak (kollektív védelem, válságkezelés, védelmi képességek fenntartása, kooperatív biztonság) megőrzése mellett a 2010. évi stratégiai koncepció megújítását, figyelembe véve a geostratégiai környezet változásait (a konfrontáció visszatérése Oroszországgal, rendszerszerü versengés Kínával) is. Az új stratégiai koncepció lehetőség is az egyértelmü stratégiai prioritások meghatározására és a NATO-kohézió megerősítésére. A jelentésben megfogalmazták, hogy a terrorizmus az egyik legközvetlenebb aszimmetrikus fenyegetés a tagországok és polgárai számára, ezért be kell emelni a

18 Secretary General appoints group as part of NATO reflection process. NATO E-Library, 31. 03. 2020. https:// www.nato.int/cps/en/natohq/news_174756.htm (Letöltés időpontja: 2021. 02. 16.)

19 NATO 2030: United for a new era... 11.; Lásd még Globális reformokra készül a NATO Donal Trump ,korszaka" és a megjegyzések után? Karpat.in.ua, 02. 12. 2020. http://politic.karpat.in.ua/?p=14856\&lang=hu (Letöltés időpontja: 2021. 02. 16.)

20 NATO 2030: United for a new era... 67.

${ }^{21}$ Ugyanerre a diszkrepanciára hívja fel a figyelmet Wagner Péter. Lásd Wagner Péter (szerk.): Miként értékeljük a NATO 2030 jelentését? Külügyi és Külgazdasági Intézet, 2021/3., 8. https://kki.hu/wp-content/uploads/2021/02/ 41 2021_03_NATO_2030.pdf(Letöltés időpontja: 2021.03. 10.)

22 NATO 2030: United for a new era... 12-15. 
terrorizmus elleni küzdelmet a NATO fő feladatai közé, valamint fokozni kell a terrorizmus elleni küzdelmet a hibrid és kiberhadviselés terén is.

Az Oroszországi Föderáció a fő katonai fenyegetés az elkövetkező évtizedben a Szövetség számára, ezért folytatnia kell a kettős megközelítés stratégiáját (dual-approach), az elrettentést, viszont nyitottnak kell maradnia a párbeszédre is. Politikailag egységesen kell fellépnie az orosz agresszióval szemben, megpróbálva visszatéríteni Oroszországot a nemzetközi jog tiszteletéhez. Az egységes fellépés a politikai kohézió jele és az elrettentés hatásos alapja is egyben.

Több időt és erőforrást kell fordítani a Kína által támasztott biztonsági kihívásoknak az ország képességei, gazdasági fellendülése és ideológiai céljainak értékelése alapján. A Szövetségnek politikai stratégiát kell kidolgoznia egy olyan világban, amelyben Kína 2030-ig növekvő jelentőségü lesz. A jelentés érdekesen fogalmaz, mert Kína egyszerre lehetőség és kihívás, ugyanakkor a szakértők a jelentésben hangsúlyosan csak az utóbbival foglalkoznak.

Javasolták egy konzultatív testület felállítását, ahol megvitathatják a NATO Kínával kapcsolatos biztonsági érdekeit, figyelemmel kísérhetik a kínai technológiai fejlődés következményeit, amelyek befolyásolhatják a Szövetség kollektív védelmét, a katonai készültségét és az ellenálló képességét. Következetes és koherens megközelítést kell alkalmazni a déli szárnyon és irányban, figyelemmel mind a hagyományos fenyegetésekre, mind pedig Oroszország és kisebb mértékben Kína növekvő jelenlétére a térségben.

A NATO-nak a hatékony nukleáris elrettentés mellett erősítenie kell a fegyverzet-ellenőrzés támogatását a létező fegyverzet-ellenőrzési mechanizmusok kihívásai megvitatásának konzultációs fórumaként. Az új feltörekvő és diszruptív technológiák kihívást és lehetőséget jelentenek és kínálnak a NATO számára. A NATO-nak kulcsfontosságú koordináló szervezetként kell szolgálnia a tagországok közötti információmegosztás és együttmüködés terén, az EDT-k minden olyan területén, amely kihat a biztonságukra. Az EDT-kben való dominancia elérése stratégiai prioritás.

Az éghajlatváltozás is alakítja a NATO biztonsági környezetét. A szakértők az Éghajlat és Biztonság Kiválósági Központ (Centre of Excellence on Climate and Security) létrehozását javasolják, valamint azt, hogy az éghajlatváltozás és más nem katonai fenyegetések, például a járványok kerüljenek be a NATO ellenálló képessége és válságkezelése tervezésébe. A NATO-nak felül kell vizsgálnia a 2014. évi Green Defence keretrendszert, ${ }^{23}$ és stratégiailag jobban kell hasznosítania a Tudomány a Békéért és Biztonságért Programot.

A jelentés foglalkozik a hibrid és a kiberfenyegetésekkel is, valamint a tagországok támogatásával a hibrid és a kibertámadások elleni küzdelemben. Ehhez nagyobb tudatosság szükséges a hibrid fenyegetésekkel kapcsolatban, valamint átfogó program kidolgozása a hibrid fenyegetések leküzdése és az ellenálló képesség kialakítása érdekében. A világür is hangsúlyosan szerepel a jelentésben. A NATO-nak a transzatlanti térség ürbiztonságával kapcsolatos alapvető konzultációs fórumnak kell lennie, azaz a világürt is be kell vonni az ellenálló képesség tervezésébe, biztosítani kell a békés célú hozzáférést a világürhöz, valamint elő kell segíteni a párbeszédet a magánszektorral.

\footnotetext{
${ }^{23}$ NATO and its partners become smarter on energy. NATO E-Library, 07. 04. 2015. https://www.nato.int/cps/en/ natohq/news_118657.htm (Letöltés időpontja: 2021. 02. 28.); lásd még Kristian Knus Larsen: Unfolding Green Defense - Linking green technologies and strategies to current security challenges in NATO and the NATO member states. Centre for Military Studies, 12. 2015, 5-14. https://cms.polsci.ku.dk/publikationer/unfolding-green-defense/ Undfolding_Green_Defense_CMS-rapport.pdf (Letöltés időpontja: 2021. 03. 20.)
} 


\section{AJÁNLÁSOK A POLITIKAI KOHÉZIÓRÓL ÉS A POLITIKAI KONZULTÁCIÓRÓL}

A NATO 2030 jelentés meghatározó fejezete az Ajánlások: a NATO szerepének, kohéziójának és konzultációjának erösitése, amely kitér a tagországok egymás közötti, az Európai Unióval mint a legfontosabb szövetségessel, valamint a partnerországokkal folytatott politikai konzultációra.

A politikai egység és kohézió, a transzatlanti konzultáció, a szövetségi és a nemzeti politika összehangja 1956 óta visszatérö kérdések a Szövetség életében.

A politikai kohéziónak és az egység fenntartásának egyértelmü prioritásnak kell lennie az Atlanti-óceán mindkét partján fekvő tagországok számára, továbbá meg kell erősíteniük elkötelezettségüket az euroatlanti térség védelmének elsődleges intézménye, a NATO iránt. A NATO-nak ezért meg kell fontolnia a Demokratikus Ellenálló Képesség Kiválósági Központ (Centre of Excellence for Democratic Resilience) létrehozását. A jelentés szorgalmazza a transzatlanti konzultáció és a legfontosabb stratégiai és politikai kérdésekben folytatott konzultáció valódi fóruma, a NAC szerepének erősítését. A tagországoknak arra kell törekedniük, hogy a nemzeti politikát a szövetségi politikához igazítsák.

A NATO hatékonyságának javítása érdekében a szakértők olyan intézkedéseket javasolnak, amelyek az addig sérthetetlennek és érinthetetlennek vélt/tartott szövetségi alapelvekhez, ezek közül is a konszenzusos döntéshozatalhoz - amely a Szövetség egyik sarokköve is hozzányúltak. A jelentésben javasolják a vétójog korlátozását, ezzel mintegy enyhítendő az egyhangú döntés elvét. Megfontolás tárgya lehet egy olyan strukturáltabb mechanizmus létrehozása, amely lehetővé tenné önkéntes ad hoc koalíciók megalakítását a NATO-n belül, hogy a Szövetség a jövőben akkor is aktív lehessen/maradhasson, ha nem minden tagja ért egyet az adott misszióval.

Az ad hoc koalíciók kialakítására vonatkozó javaslat nem új jelenség. Az egyes müveletekkel és a tagországok elkötelezettségével kapcsolatban természetesen már korábban is voltak komoly viták a Szövetségen belül: az iraki háború kapcsán formálódott a „,coalition of willingness”, a líbiai légicsapások esetében pedig a „,coalition of capables” formájában. Az előbbinél a mủveletben részt venni szándékozók, az utóbbiban pedig a müvelethez hozzájárulni képes országok vettek részt.

Javasolták egy felsőoktatási központ létrehozását a NATO-tagországokon kívüli jövőbeli tehetségek segítésére, valamint a NATO Védelmi Akadémia ${ }^{24}$ sikerességét alapul véve a NATO Egyetem (NATO University) alapítását. A Harmel-ösztöndíj Program (Harmel Fellowship Program) keretében az egyes tagországok évente egy-egy személy posztgraduális tanulmányait finanszírozhatják egy másik NATO-tagország vezető egyetemén.

A szakértők konkrét javaslatokat fogalmaztak meg a NATO és az Európai Unió közötti együttmüködéssel kapcsolatban: egyeztetést a soron következő csúcsértekezleten a két szervezet között, valamint intézményesített kapcsolat, állandó politikai kapcsolattartó elem létrehozását a Nemzetközi Törzsben (International Staff, IS) és az Európai Külügyi Szolgálatnál (European External Action Service, EEAS).

\footnotetext{
${ }^{24}$ A NATO Védelmi Akadémia a Szövetség egyetlen stratégiai szintű oktatási intézménye, erről részletesen lásd Siposné Kecskeméthy Klára: History of the NDC. Academic and Applied Research in Military Science, Vol. 4, Issue 3, 2005, 463-474.
} 


\section{POLITIKAI KONZULTÁCIÓ A PARTNEREKKEL}

„Az ajtónak nyitva kell maradnia minden európai demokrácia számára, amely csatlakozni szeretne a NATO-hoz." ${ }^{25}$

A politikai konzultáció harmadik pillére a jelenlegi és a jövőbeni partnerországokkal és kezdeményezésekkel folytatott együttmüködés. NATO partnerségi kezdeményezései a kooperatív biztonság megteremtésének kulcsfontosságú eszközei. Számos partnerország osztozik a Szövetség alapértékeivel, a demokrácia, a szabadság és a jogállamiság alapelveivel, emellett hozzájárulnak a nemzetközi békéhez és stabilitáshoz. ${ }^{26} \mathrm{~A}$ partnerségi kezdeményezések stabilizáló eszközként szolgálnak a NATO-tagországok területén kívüli régiói számára, emellett a Szövetség segíti a partnerek védelmi képességfejlesztését és az interoperabilitás elérését. A NATO és partnerei országspecifikus gyakorlati együttmüködése nemcsak a múveleti sikerekhez járult/járul hozzá, de segíti az egyes régiók biztonsági problémáinak kezelését is, mielőtt azok begyürüznének a tagországok területére.

A NATO 2030 jelentésben a Szövetség partnerkapcsolataira vonatkozóan számos ajánlást fogalmaztak meg.

Mindenekelött a Szövetségnek a jövőben stratégiai szinten tudatosabban kell a partnerségekben rejlö lehetőségeket megragadni, globális tervet kell kidolgoznia arra vonatkozóan, hogy a különböző régiók partnerségi kezdeményezéseit miként lehet felhasználni a NATO stratégiai érdekeinek előmozdítása érdekében egy új, geopolitikai versengéssel jellemzett korszakban. Az erőfeszítés részeként a NATO-nak felül kell vizsgálnia és élénkítenie kell a meglévő partnerségeket, hogy áttérhessen a jelenlegi igényalapú (demand-driven approach) megközelítésről az érdekalapú (interest-driven approach) megközelítésre. Az előbbi esetben a partnerországok határozzák meg a partnerségi együttmüködés körét és mélységét, az utóbbinál a NATO - a stratégiai szükségletei és a rendelkezésre álló erőforrásai alapján prioritásokat állít fel a partnerekkel történő együttmúködésre vonatkozóan. Ehhez stabil és kiszámítható erőforrások biztosítása szükséges a partnerségi kezdeményezések számára, mert nem áll rendelkezésre elegendő forrás a létező partnerségi programok fejlesztésére, és az esetleges új kapcsolatok létesítésére. A regionális partnerségi keretek hatékony müködtetése érdekében mind a Szövetségnek, mind a partnereknek világosan meg kell határozniuk a kölcsönös elvárásokat és célokat, ezért az ilyen kezdeményezések időről időre történő értékelése elengedhetetlen. A NATO és a partnerségi kezdeményezések változásait az 1. táblázat szemlélteti.

1. táblázat A NATO partnerségi politika változásai 1994-2020 között (Szerkesztette a szerzö)

\begin{tabular}{|l|l|l|}
\hline Év & Partnerségi kezdeményezés & Célkitűzés \\
\hline $1994-2011$ & $\begin{array}{l}\text { Partnerség a Békéért kezdeményezés } \\
\text { országai }\end{array}$ & Partnerség a tagságért \\
\hline $1994-2011$ & $\begin{array}{l}\text { Mediterrán Párbeszéd, az Isztambuli } \\
\text { Együttmúködési Kezdeményezés } \\
\text { országai és a Globális Partnerek }\end{array}$ & Széles körű együttműködés \\
\hline
\end{tabular}

\footnotetext{
${ }^{25}$ NATO 2030: United for a new era... 57.

${ }^{26}$ Uo. 57-60.
} 


\begin{tabular}{|l|l|l|}
\hline Év & Partnerségi kezdeményezés & Célkitüzés \\
\hline $2011-2020$ & $\begin{array}{l}\text { Berlini Partnerségi Politika } \\
\text { Új, rugalmas és hatékony partnerség, } \\
\text { kooperatív együttmüködés }\end{array}$ & $\begin{array}{l}\text { Partnerség a partnerségért } \\
\text { Igényalapú partnerség } \\
\text { A partnerországok határozzák meg } \\
\text { az együttmüködés területeit }\end{array}$ \\
\hline $2020-$ & $\begin{array}{l}\text { A földrajzi alapon szervezett } \\
\text { partnerségi kezdeményezések } \\
\text { helyett tematikai alapú } \\
\text { együttmüködés }\end{array}$ & $\begin{array}{l}\text { Érdekalapú partnerség } \\
\text { A partnerekkel történő együtt- } \\
\text { müködés a NATO stratégiai } \\
\text { szükségletei és erőforrásai alapján }\end{array}$ \\
\hline
\end{tabular}

2030-ra elöretekintve a Szövetségnek egyrészt mélyíteni kell az együttműködést az Indiaiés a Csendes-óceán térségében található partnerekkel (Ausztrália, Új-Zéland, Koreai Köztársaság), másrészt új partnerségi kapcsolatokat kell kialakítania. Ez a meglévő NATO + 4 formátum (NATO+4 Format), a NATO-Csendes-óceáni Partnerségi Tanács (NATO-Pacific Partnership Council) felhasználásával, a Négyoldalú Biztonsági Párbeszéddel (Quadrilateral Security Dialogue), adott esetben együttmüködve más államokkal (pl. India) valósulhat meg. Kína felemelkedésének stratégiai és politikai következményei miatt szükséges a koordináció, az információmegosztás, a rendszeres párbeszéd, a technológiai együttmüködés és a $\mathrm{K}+\mathrm{F}$. A NATO bővíteni szándékozik a partnerek körét Indiával és Ázsia más országaival. India jövőbeni partnerségéről a Szövetségen belüli egyeztetés megkezdése fontos lehet. A Svédországgal és Finnországgal kialakított kapcsolat modellértékü lehet a más régiókban folytatott partnerség fejlesztésére vonatkozóan.

A Washingtoni Szerződés 10. cikke világosan megfogalmazza a nyitott ajtó politikáját (open door policy), a Szövetség nyitott minden olyan európai demokrácia előtt, amely csatlakozni akar és hozzájárul az euroatlanti térség biztonságához. ${ }^{27}$ A nyitott ajtó politikája az Észak-atlanti Szerződés egyik alapelve, kulcsfontosságú a partnerek integrációjában és a tagságra történő felkészülésben. Stratégiai prioritás a partnerség megerősítése és bővítése a tagságra aspiráló Ukrajnával és Georgiával. A Nyugat-Balkán destabilizációjának megakadályozása érdekében fokozni kell az együttmüködést Bosznia-Hercegovinával.

Visszatérő gondolat a Mediterrán Párbeszéd és az Isztambuli Együttmüködési Kezdeményezés fejlesztése a politikai elkötelezettség, a képességfejlesztés és az ellenálló képesség fokozása révén. ${ }^{28} \mathrm{~A}$ déli régióból érkező széles körü kihívások (éghajlatváltozás, illegális migráció, erőforrások szűkössége) és azok földrajzi kiterjedése miatt erősíteni kell a jelenlétet és együttműködést az Afrikai Unióval, a Száhel-övezet G5 országaival és

${ }^{27}$ Az Észak-atlanti Szerződés. Washington DC, 1949. április 4. NATO E-Library. https://www.nato.int/cps/en/natohq/ official_texts_17120.htm?selectedLocale=hu (Letöltés időpontja: 2021. 02. 16.)

${ }^{28}$ Siposné Kecskeméthy Klára: Mediterráneum: átalakuló NATO-partnerség. In: Molnár Anna - Komlósi Orsolya (szerk.): Az Európai Unió mediterrán térséggel összefüggő kapcsolata - Párbeszédek és konfliktusok. Dialóg Campus Kiadó, Budapest, 2019, 205-229. https://nkerepo.uni-nke.hu/xmlui/bitstream/handle/123456789/13032/ Web_PDF_Az\%20EU_mediterran_terseggel_osszefuggo_kapcsolata.pdf?sequence=1 (Letöltés időpontja: 2021. 03. $\overline{20}$.) 
más multilaterális szervezetekkel. ${ }^{29}$ A védelmi képesség- és intézményfejlesztés (Defence Capacity and Institution Building, DCIB) erőfeszítéseinek fokozása a térségben, a Tunéziával és Jordániával megszerzett tapasztalatok előremutatók lehetnek. Növelni és javítani kell a NATO ismertségét a déli irány partnerei számára. Megfontolandó a Mediterrán Párbeszéd Regionális Központjának (Regional Centre for the Mediterranean Dialogue) létrehozása, hasonlóan a Kuvaitban alapított és müködő Regional Centre in Kuwait of the Istanbul Cooperation Centre-hez.

A NATO 2030 jelentés szerint a Szövetségnek a földrajzi alapon szervezett és csoportosított partnerségi kezdeményezések helyett a tematikai alapú együttmüködésekre kell fókuszálnia. Bár a jelentés új gondolatának tartják ezt a megállapítást, ugyanakkor a földrajzi alapon szervezett partnerségi kezdeményezések átalakítására vonatkozóan az elmúlt másfél évtizedben már számos javaslat született. A biztonságpolitikai szakértők és maga a Szövetség is többször tettek kísérletet a partnerországok hatékony együttmüködési szervezetére, regionális felosztására és csoportosítására.

Jeffrey Simon 2004-ben a húsz partnert és két PfP-aspiráns országot (Bosznia-Hercegovina, valamint Szerbia és Montenegró) a rendkívül különböző igényeik, érdekeik, képességeik és földrajzi elhelyezkedésük alapján osztotta csoportokra. ${ }^{30}$ Carlo Masala és Katariina Saarilouma 2006 májusában tekintették át a Szövetség partnerségi kapcsolatait, az egyes kezdeményezések előnyeit és hátrányait, valamint kísérletet tettek a meglévő geográfiai keretek helyett a partnerségi struktúra szervezeti és funkcionális alapon történő újjászervezésére. ${ }^{31}$

2011 áprilisában a NATO-tagállamok külügyminiszterei új partnerségi politikát fogadtak el, az ún. Berlini Partnerségi Csomagot (Berlin Partnership Package, BPP), ${ }^{32}$ melynek fö célkitüzése a hatékonyabb és rugalmasabb partnerségi politika, az egységes partnerségi eszköz és keret bevezetése volt. ${ }^{33}$

A partnerségi politikában alapvető szemléletváltozás következett be, a „,partner for membership” helyett a „partner for partnership” megközelítés, az értékalapú közösség fontossága mellett a biztonság kooperatív megközelítése vált központi kérdéssé. Az új partnerségi politika a meglévő és a potenciális partnereknek megadta a lehetőséget arra, hogy saját maguk határozzák meg kapcsolatrendszerüket a Szövetséggel, hogy milyen partnerségi tevékenységben kívánnak részt venni, illetve kezdeményeznek-e párbeszédet a szervezettel.

${ }^{29}$ A kooperatív biztonság és főleg a bizalomerősítés gyakorlatára jó példa az EBESZ munkája. Lásd Remek Éva: Az Európai Biztonsági és Együttmúködési Szervezet: párbeszéd Vancouvertől Vlagyivosztokig. Zrínyi Kiadó, Budapest, 2020, 97-98. https:/nkerepo.uni-nke.hu/xmlui/bitstream/handle/123456789/16174/Remek EBESZ_t\%F6rdelt.pdf?sequence=1 (Letöltés időpontja: 2021. 03. 20.)

30 Jeffrey Simon: Partnership for Peace: Charting a Course for a New Era. Strategic Forum, No. 206, 03. 2004. https:/www.hsdl.org/?view\&did=448166 (Letöltés időpontja: 2021. 03. 20.)

${ }^{31}$ Carlo Masala - Katariina Saariluoma: Renewing NATO's Partnerships: Towards a Coherent and Efficient Framework. Forum Paper Series, No 1, 06. 2006. NATO Defense College, Rome. http://www.ndc.nato.int/download/ publications/fp_01.pdf (Letöltés időpontja: 2021. 02. 26.)

32 Active engagement in cooperative security: a more efficient and flexible partnership policy. http://www.nato.int/ nato_static/assets/pdf/pdf_2011_04/20110415_110415-Partnership-Policy.pdf(Letöltés időpontja: 2021. 03. 01.)

${ }^{33}$ Klára Siposné Kecskeméthy: Milestones - NATO adaptation to changing security environments. Právo a bezpečnost', číslo 3. ročník 2018, 183-192. https://www.vske.cz/data/ke_stazeni/pravo_a_bezpecnost/Pravo_a_ bezpecnost_3-2018.pdf (Letöltés időpontja: 2021.03.01.) 
A partnerségi programokra rendelkezésre álló erőforrások már akkor is szükségessé tették a prioritások felállítását. ${ }^{34}$

Karl-Heinz Kamp és Heidi Reisinger 2013-ban - figyelembe véve a BPP hatékonyságát és rugalmasságát - háromkörös modellt vázolt fel, amely a földrajzi határok, a korábbi partnerségi keretek nélkül tette lehetővé a különböző európai, ázsiai és közel-keleti országokkal a széles körü együttmüködést, anélkül hogy a közös politikai elvek és értékek elvárásként fogalmazódtak volna meg. A partnereket három kategóriába sorolták: 1. párbeszédországok (Advanced Partners); 2. együttmüködő partnerek (Cooperation Partners); 3. kiemelt partnerek (Dialogue Countries). ${ }^{35}$

2014-ben a walesi csúcsértekezlet zárónyilatkozatában ${ }^{36}$ részben visszaköszöntek a Kamp-Reisinger-féle kategóriák. Elfogadták a Partnerségi Interoperabilitási Kezdeményezést (Partnership Interoperability Initiative, PII) és az Interoperabilitási Platformot (Interoperability Platform, IP). Az IP-n belül található kiemelt partnerek (Enhanced Partners) ${ }^{37}$ hozzáférnek az operatív tervezéshez, a gyakorlatokon történő részvételhez, valamint rendszeres politikai konzultációt folytathatnak a Szövetséggel. Elindították a Védelmi Képességfejlesztési Kezdeményezést (Defence and Related Security Capacity Building Initiative, DCBI) a biztonsági szektor reformja és az intézményfejlesztés, a képzés és a kiképzés támogatása, a védelmi képességek és a helyi erők fejlesztésének segítése érdekében.

\section{ÖSSZEGZÉS}

„A politikai alkalmazkodás létfontosságú a NATO számára, de egyben a túlélés követelménye is." ${ }^{8}$

A NATO 2030 - Egységben egy új korszakért jelentés alapvetően egy átfogó önvizsgálati folyamat, egy közös előregondolkodás, értékes összegzés és feladatlista. Számos stratégiai feladatot fogalmazott meg a Szövetség számára a kulcsfontosságú kényszerek figyelembevételével. A jelentés központi eleme az egyik legfontosabb stratégiai prioritás, vagyis egy új, a nemzetközi környezetben végbement változásokhoz igazított, azt tükröző, arra reflektáló stratégiai koncepció megalkotásának a szükségessége és annak a soron következő csúcsértekezleten történő elfogadása. Ez egyben iránymutatás a Szövetség és a tagországok számára.

A posztbipoláris korszakban a NATO folyamatosan reagált a biztonsági környezet változásaira. Az 1990-es években az együttműködés a kelet-közép-európai országokkal és

\footnotetext{
${ }^{34}$ Siposné Kecskeméthy Klára: Partnerség a békéért - 20 év tapasztalatai. In: Kiss Petra - Zsolt Melinda (szerk.): NATO Partnerség 2014 - A szövetségi partnerségi programok múltja, jelene és jövője. Nemzeti Közszolgálati Egyetem, Budapest, 2014, 21-52. http://m.ludita.uni-nke.hu/repozitorium/bitstream/handle/11410/8591/Teljes\%20 sz\%c3\%b6veg\%21?sequence=1\&isAllowed=y (Letöltés időpontja: 2021. 03. 20.)

${ }^{35}$ Karl-Heinz Kamp - Heidi Reisinger: NATO’s partnership after 2014: Go West! Research Paper No. 92. NATO Defence College, Rome, 2013. https:/www.files.ethz.ch/isn/164202/rp_92.pdf (Letöltés időpontja: 2021. 03. 20.)

${ }^{36}$ Wales Summit Declaration - Issued by the Heads of State and Government participating in the meeting of the North Atlantic Council in Wales. NATO E-Library, 05. 09. 2014., 83-85. pontok. http://www.nato.int/cps/en/ natohq/official_texts_112964.htm (Letöltés időpontja: 2021. 03. 10.)

${ }^{37}$ Az Interoperabilitási Platform 24 országa között megtaláljuk a MENA-régióból Bahreint, az Egyesült Arab Emírségeket, Jordániát és Marokkót.

38 NATO 2030: United for a new era... 64.
} 
a bővítés, 2001-től a terrorizmus elleni küzdelem, 2014-től pedig az orosz kihívásra adott válaszok és a kollektív védelem megerősítése állt a középpontban. Napjaikban a Szövetség rendkívül változatos, sok irányból érkező fenyegetésekkel szembesül. A NATO alapítása óta a tagországok számára a politikai kohézió és a szervezet egységének fenntartása fontos stratégiai alapvetés volt. Az utóbbi időszakban megkérdőjeleződött a transzatlanti konzultáció és a konszenzus fontossága, valamint az egységes fellépés szükségessége, éppen ezért a jelentésben javaslatokat fogalmaztak meg a Szövetség konzultációs mechanizmusáról. A NATO hatékonyságának javítása érdekében a szakértők eddig sérthetetlen/érinthetetlen alapelveket is érintettek. A konszenzusos döntéshozatallal kapcsolatban megfogalmazták a vétójog korlátozását.

A jelentés elsősorban a NATO alapfeladataira, a kollektív védelemre fókuszál, a Szövetség felelősségi körzetén túli stabilitás kivetítése sokkal kevésbé hangsúlyos. A NATO szerepének, kohéziójának és a konzultáció erősítése címü fejezet kitér a feltörekvő és diszruptív technológiákra, a terrorizmusra, a déli szárnyról és irányból érkező hagyományos és új fenyegetésekre, az energiabiztonságra, a klímaváltozásra, a humánbiztonságra és a nők helyzetére, a járványokra és a természeti katasztrófákra, valamint a hibrid- és kiberfenyegetésekre, valamint a világürre is.

A Szövetség a nagyhatalmi konfliktusok és a geopolitikai szereplök rivalizálásának visszatérése okán két kihívóval, Oroszországgal és Kínával szembesül. Oroszország marad 2030-ig a NATO számára a legfőbb katonai fenyegetés, éppen ezért továbbra is az elrettentés és a párbeszéd kettős stratégiájával kell visszatéríteni a nemzetközi jog tiszteletéhez. A 2030-ig terjedő időszakban Kína növekvő jelentőségü lesz, ezért a Szövetségnek több időt, erőforrást és figyelmet kell fordítania a Kína által támasztott biztonsági kihívásokra. Politikai stratégiát kell kidolgoznia - ez ügyben a jelentés diplomatikusan fogalmaz -, mert az elkövetkező évtizedben Kína egyszerre jelent lehetőséget, de komoly kihívást is. Ám a szövetségesek között Kína jelentőségének és szerepének megítélésében - a globális kitekintésü Amerika és a regionális fókuszú Európa - különbség van, így ennek feloldása a jövő fontos feladata lesz.

A jelentés a politikai konzultáció három területét érinti: a tagországok, az Európai Unió és a partnerségi kezdeményezések országai között folytatott konzultációt. Lényegi változás lehet az, ha a Szövetség megváltoztatja a jellemzően földrajzi alapon szervezett partnerségi kereteket és rendszereket. Elötérbe kerül egy olyan globális partnerségi terv kidolgozása, ahol a NATO stratégiai érdekeinek előmozdítása érdekében kell a partnerségi kezdeményezések országaival hatékonyabban együttmüködni. Ennek megfelelően az eddigi igényen alapuló (demand-driven approach) megközelítés egy érdekalapú megközelítésre változhat, amelyben a NATO a stratégiai szükségletei és a rendelkezésre álló erőforrásai alapján állít fel prioritásokat a partnerekkel történő együttmüködésre vonatkozóan. Ehhez az új elveknek megfelelő átgondolt partnerségi stratégiára, valamint stabil és kiszámítható erőforrásokra van szükség.

A szakértők azzal a pozitív gondolattal zárják a jelentést, hogy ha a NATO az elmélkedésröl a konkrét gyakorlati lépések megtételére tér át, akkor a Szervezet továbbra is a szövetségesek kollektív védelmének a sarokköve, valamint a béke és a biztonság őrzője marad. Az elkövetkező évtized fejleményei és eseményei majd választ adnak erre. 


\section{FELHASZNÁLT IRODALOM}

Active engagement in cooperative security: a more efficient and flexible partnership policy. http://www. nato.int/nato_static/assets/pdf/pdf_2011_04/20110415_110415-Partnership-Policy.pdf

Az Észak-atlanti Szerződés. Washington DC, 1949. április 4. NATO E-Library. https://www.nato.int/ cps/en/natohq/official_texts_17120.htm?selectedLocale $=$ hu

Defence Expenditure of NATO countries (2013-2020). 21. 10. 2020. NATO Press Release, Communique PR/CP(2020)104, 21. 10. 2020. https://www.nato.int/nato_static_fl2014/assets/pdf/ 2020/10/pdf/pr-2020-104-en.pdf

Emmanuel Macron warns Europe: NATO is becoming brain-dead. The Economist, 07. 11. 2019. https://www.economist.com/europe/2019/11/07/emmanuel-macron-warns-europe-nato-is-becomingbrain-dead

Gazdag Ferenc: Az elsö negyven év. A NATO 1949-1989 között. In: Dunay Pál - Gazdag Ferenc: Az Észak-atlanti Szerződés szervezete - Tanulmányok és dokumentumok. Stratégiai és Védelmi Kutatóintézet, Budapest, 1997, 21-55.

Globális reformokra készül a NATO Donal Trump „korszaka” és a megjegyzések után? Karpat.in.ua, 02. 12. 2020. http://politic.karpat.in.ua/?p=14856\&lang=hu

Information on defence expenditures. NATO E-Library, 16. 03. 2021. https://www.nato.int/cps/en/ natohq/topics_49198.htm?selectedLocale=en

Kamp, Karl-Heinz - Reisinger, Heidi: NATO's partnership after 2014: Go West! Research Paper No. 92. NATO Defence College, Rome, 2013. https://www.files.ethz.ch/isn/164202/rp_92.pdf

Káncz Csaba: Így kerüli meg hazánkat a NATO és az EU - betelt a pohár. Privátbankár, 2020. 12. 04. https://privatbankar.hu/cikkek/makro/igy-keruli-meg-hazankat-a-nato-es-az-eu--betelt-a-pohar.html

Larsen, Kristian Knus: Unfolding Green Defense - Linking green technologies and strategies to current security challenges in NATO and the NATO member states. Centre for Military Studies, 12. 2015. https://cms.polsci.ku.dk/publikationer/unfolding-green-defense/Undfolding_Green_Defense_CMSrapport.pdf

Masala, Carlo - Saariluoma, Katariina: Renewing NATO's Partnerships: Towards a Coherent and Efficient Framework. Forum Paper Series, No. 1, 06. 2006. NATO Defense College, Rome. http:// www.ndc.nato.int/download/publications/fp_01.pdf

NATO 2030: United for a new era - Analysis and recommendations of the Reflection Group appointed by the NATO Secretary General. Brussels, 25. 10.2020. https://www.nato.int/nato_static_fl2014/ assets/pdf/2020/12/pdf/201201-Reflection-Group-Final-Report-Uni.pdf

NATO and its partners become smarter on energy. NATO E-Library, 07. 04. 2015. https://www.nato. int/cps/en/natohq/news_118657.htm

Reflections on the status and future of the transatlantic alliance $>$ Security \& Defence Agenda. 10. 06. 2011. https://www.europarl.europa.eu/meetdocs/2009_2014/documents/sede/dv/sede190911 robertgates_/sede190911robertgates_en.pdf

Remarks by Donald Trump, President of the United States at the dedication of the 9/11-Article 5 Memorial. https://www.nato.int/nato_static_fl2014/assets/audio/audio_2017_05/20170525_170525f.mp3

Remek Éva: Az Európai Biztonsági és Együttmüködési Szervezet: párbeszéd Vancouvertöl Vlagyivosztokig. Zrínyi Kiadó, Budapest, 2020. https://nkerepo.uni-nke.hu/xmlui/bitstream/handle/123456789/16174/ Remek_EBESZ_t\%F6rdelt.pdf?sequence=1

Science for Peace and Security Programme. NATO E-Library, 18. 08. 2020. https://www.nato.int/cps/ en/natohq/topics_85373.htm

Secretary General appoints group as part of NATO reflection process. NATO E-Library, 31. 03. 2020. https://www.nato.int/cps/en/natohq/news_174756.htm 
Simon, Jeffrey: Partnership for Peace: Charting a Course for a New Era. Strategic Forum, No. 206. 03. 2004. https://www.hsdl.org/?view\&did=448166

Siposné Kecskeméthy Klára: History of the NDC. Academic and Applied Research in Military Science, Vol. 4, Issue 3, 2005, 463-474.

Siposné Kecskeméthy Klára: Mediterráneum: átalakuló NATO-partnerség. In: Molnár Anna-Komlósi Orsolya (szerk.): Az Európai Unió mediterrán térséggel összefüggő kapcsolata - Párbeszédek és konfliktusok. Dialóg Campus Kiadó, Budapest, 2019, 205-229. https://nkerepo.uni-nke.hu/xmlui/ bitstream/handle/123456789/13032/Web_PDF_Az\%20EU_mediterran_terseggel_osszefuggo_ kapcsolata.pdf? sequence $=1$

Siposné Kecskeméthy, Klára: Milestones - NATO adaptation to changing security environments. Právo a bezpečnost', číslo 3. ročník 2018, 183-192. https://www.vske.cz/data/ke_stazeni/pravo_a_ bezpecnost/Pravo_a_bezpecnost_3-2018.pdf

Siposné Kecskeméthy Klára: Partnerség a békéért - 20 év tapasztalatai. In: Kiss Petra - Zsolt Melinda (szerk.): NATO Partnerség 2014 - A szövetségi partnerségi programok múltja, jelene és jövője. Nemzeti Közszolgálati Egyetem, Budapest, 2014, 21-52. http://m.ludita.uni-nke.hu/repozitorium/ bitstream/handle/11410/8591/Teljes\%20sz\%c3\%b6veg\%21?sequence=1\&isAllowed=y

Szenes Zoltán - Siposné Kecskeméthy Klára: NATO 4.0 and Hungary; 20 years of membership, 30 years of cooperation. Zrínyi Kiadó, Budapest, 2019.

The Harmel Report: full reports by the rapporteurs on the future tasks of the Alliance. http://www.bits. de/NRANEU/nato-strategy/Harmel_Report_complete.pdf

Transcript: Donald Trump on NATO, Turkey's Coup Attempt and the World. The New York Times, 21. 07. 2016. https://www.nytimes.com/2016/07/22/us/politics/donald-trump-foreign-policy-inter view.html;

Wagner Péter (szerk.): Miként értékeljük a NATO 2030 jelentését? Külügyi és Külgazdasági Intézet, 2021/3. https://kki.hu/wp-content/uploads/2021/02/41_2021_03_NATO_2030.pdf

Wales Summit Declaration - Issued by the Heads of State and Government participating in the meeting of the North Atlantic Council in Wales. NATO E-Library, 05. 09. 2014. http://www.nato.int/ cps/en/natohq/official_texts_112964.htm 